\title{
Consumer attitudes toward information displayed at food buffets in commercial restaurants
}

\author{
Atitude dos consumidores frente às informações alimentares dispostas em bufê de \\ restaurante comercial
}

\author{
Tatiana BARBIERI ${ }^{1}$, Karina de Souza RODRIGUES ${ }^{1}$, Simone Ferreira da SILVA ${ }^{1}$, \\ Laissa Benites MEDEIROS ${ }^{1}$, Ana Lúcia de Freitas SACCOL ${ }^{1 *}$
}

\begin{abstract}
This study aimed to evaluate the attitude of consumers towards information about dishes in a commercial restaurant. This research was conducted from January to April 2009 in a restaurant in the city of Santa Maria (RS), Brazil. Food information including the name of the dish, ingredients, health benefits and warnings, and calorie value was displayed. After providing this nutritional information, a questionnaire was applied to 300 consumers at the restaurant to observe their attitudes towards the food information. It was found that $10.57 \%$ of the respondents reported allergy or intolerance to some kinds of food and that $10.98 \%$ of the respondents reported having diseases that require moderate consumption and/or total restriction on the consumption of those foods. However, $84.96 \%$ of the respondents did not restrict consumption of any food, even though those foods may have posed a risk to their health, and $58.54 \%$ of the respondents consumed some food due to the potential benefits to their health. With regard to the respondents' level of satisfaction concerning the food information provided, $72.76 \%$ considered the information provided as very good. The respondents had a tendency to change their behavior towards consumption after having access to information about the dishes displayed.

Keywords: nutritional information; food and nutrition education; food labeling.
\end{abstract}

\section{Resumo}

Este estudo teve como objetivo avaliar a atitude dos consumidores em relação às informações alimentares para preparações prontas em um restaurante comercial. Esta pesquisa foi realizada de janeiro a abril de 2009, em um restaurante em Santa Maria (RS), Brasil. Foram desenvolvidas informações de alimentos com o nome da preparação, ingredientes, benefícios para a saúde e alertas e valor calórico. Depois de fornecer essas informações nutricionais, um questionário foi aplicado aos 300 consumidores no restaurante para observar as atitudes dos consumidores relativamente à informação de alimentos. Verificou-se que 10,57\% dos participantes relataram apresentar alergia ou intolerância a algum tipo de alimento e que $10,98 \%$ dos participantes possuíam doença, sendo necessária a restrição de moderação e/ou total desses alimentos. No entanto, $84,96 \%$ dos participantes não deixaram de consumir algum alimento, mesmo que esses possam ter representado um risco para sua saúde, e 58,54\% dos participantes consumiram algum alimento porque observaram benefícios potenciais para a sua saúde. Ao avaliar o nível de satisfação dos participantes sobre as informações de alimentos, 72,76\% consideraram as informações muito boas. Os participantes tenderam a mudar seu consumo depois de ter acesso a informações alimentares dos alimentos preparados.

Palavras-chave: informação nutricional; educação alimentar e nutricional; rotulagem de alimentos.

\section{Introduction}

Food is a basic necessity for any society, and it influences the quality of our lives because of its relation with health maintenance, disease prevention and recovery. In order to provide such benefits, food has to be healthy, varied, complete and balanced, safe and have pleasant taste (ZANDONADI et al., 2007). Recommendations for food consumption include the amount and types of food, which often make it difficult and impractical for most people to follow (LOBANCO, 2007).

Exercising the responsibility of promoting and protecting the health of the population, the Ministry of Health promotes healthy lifestyles and good practice in healthy eating (BRASIL, 2003a).
The decrease in free time of the population was one of the factors responsible for changes in eating habits. Fast-food and out-of-home foods have become a habit for many families. People have consumed a greater quantity of products high in fat and sugar containing a low nutritional value, and they have reduced the ingestion of foods rich in fibers (SANTOS et al., 2005).

Changes in eating habits have been observed in recent decades. The consumption of food is related to information that the consumers have about the product, and they purchase and consume certain foods due to their quality or because they appear to be safe or reliable. It was also observed that culture,

${ }^{1}$ Centro Universitário Franciscano - UNIFRA, Santa Maria, RS, Brasil, e-mail: alsaccol@yahoo.com.br

${ }^{*}$ Corresponding author 
education, and other habits are factors that can interfere in the concept of quality. Currently, the attributes related to health can be important for the choice of foods by the consumers (SANCHES, 2007). Food labels are an important source of this type of information since they provide nutritional information about nutrient contents and health benefits (COUTINHO; RECINE, 2007).

The National Agency of Sanitary Surveillance (ANVISA, acronym in Portuguese) published on December $23^{\text {rd }}, 2003$, the RDC $\mathrm{n}^{\circ} 360$, which establishes technical regulations for the use of nutritional information for packaged foods and beverages in order to regulate and standardize the nutrition labeling in Brazil (BRASIL, 2003a). ANVISA also published the RDC no 359, which approved the Technical Regulation of portions of Packaged Foods for the purpose of Nutritional Labeling, determining the average amount of food that should be consumed by healthy people and infants older than 36 months on each occasion of use, in order to promote healthy eating (BRASIL, 2003b).

According to ANVISA, a label is any inscription, caption and image, or any matters described or graphic, that is written, printed, stamped, engraved, or affixed to the packaging of food (BRASIL, 2003).

Nutrition labeling and health claims are defined as a representation that suggests or implies that the food has certain characteristics concerning the origin, nutritional properties, nature, production, processing, composition, or any other quality. Based on this fact, nutrition labeling may be effective in helping consumers make the most appropriate choice regarding packaged manufactured food, but the consumer is not always able to read and interpret the nutritional information. The health claims on the labels, when appropriate, may help inform the consumer since often they are direct messages and guide the choice of consumers for certain products (COUTINHO; RECINE, 2007).

In Brazil, although important, the process of information about food safety provided to consumers in restaurants is infrequent. For example, people who suffer from food allergies require accurate information. The availability of information is of great value as an aid for the development of programs for nutritional information and regulations in restaurants (MAESTRO, 2007).

The use of nutrition information is justified as a way of helping people to improve their diets by providing consumers with useful and reliable information, encouraging the marketing of healthier products (CELESTE, 2001). Nutritional information will not necessarily cause a change in the consumer's behavior, but the specialized literature shows positive results, arguing that the majority of the public is becoming even more conscious of the importance of using nutritional information in restaurants in their choices regarding food, thus encouraging a growing number of restaurants to adhere to this policy (MAESTRO, 2007).

However, according to the RDC $\mathrm{n}^{\circ} 360$, this information is an obligation only to industrialized goods, and in Brazil, little is known about the use of nutritional information for prepared foods served in restaurants, which makes it difficult to make healthy food choices because many people are accustomed to consuming food away from home (BRASIL, 2003a).

Some commercial restaurants provide information on the energy value of the dishes they offer. These initiatives are very weak, and the government will certainly have to devise innovative ways of regulating food services so that consumers will have information available to choose an establishment according to the desired quality without sacrificing the economic efficiency of the companies (SALAY, 2001).

However, the number of restaurants that convey some type of nutritional and health information in Brazil is not known. However, these data can serve as a valuable subsidy for the development of programs involving health and nutritional information, including regulations regarding the food service industry (MAESTRO; SALAY, 2008).

Based on this assumption, the present study aimed to evaluate the attitude of consumers towards information about prepared meals served in commercial restaurants.

\section{Materials and methods}

A quantitative research analysis was conducted from January to April 2009 in a commercial restaurant in Santa Maria, RS.

The venue where the study was conducted was selected based on an interview with the owner of the restaurant concerning the following criteria: availability of resources necessary to conduct the research, space in the buffet for presenting the information, interest in participating in this study, presence of a nutritionist in the establishment, and serving self-service meals (pay-per kilo) in the buffet.

After the selection of the venue, a study of the served preparations was carried out. The day before each experiment, these dishes as well as their ingredients and their recipes were thoroughly analyzed. The method proposed by Luna (1995) was used to determine the number of grams per food preparation. The correction factor of the food was calculated according to Luna and Teixeira (1996). The yield determination was performed by weighing the prepared dishes using an electronic balance (PRIX III, Toledo). The remaining dishes were calculated using the cooking factor table found in Araújo and Guerra (1995).

After obtaining the data, the number of calories for each preparation was calculated using two supplementary tables of food composition: TACO (Brazilian Table of Food Composition), developed by the center for studies and research on food (UNIVERSIDADE..., 2004), and the table of food composition of the Brazilian Institute of Geography and Statistics (INSTITUTO..., 1996). The portion size with the amount of calories served to the consumers was obtained from the RDC no 359 (BRASIL, 2003b). After that, each preparation was characterized according to Leão and Gomes (2006) and Mahan and Escott-Stump (2005). The information compiled on each food included the possible benefits, the presence of any 
ingredient detrimental to the health of the consumers, or the presence of lactose or gluten.

The food information adapted from Oliveira (2008) contained the following information: name of the dish, ingredients, health benefits and warnings, calorie value, and serving size and weight of the portion, as illustrated in Figure 1. The research was conducted on three weekends (Saturday) in March and one business day in April 2009. The food information was posted on the self-service buffet so that customers could easily read the relevant information; the information was removed or replaced according to necessity.Along with the food information, an informative booklet containing information on protein, carbohydrates, lipids, and micronutrients such as vitamin $A, D, E, K, C$, complex B, and minerals such as calcium, magnesium, iron, zinc, copper, iodine, phosphorus, potassium, sodium, chlorine, and selenium was prepared based on Craveiro and Craveiro (2003), Mura and Silva (2007), and Waitzberg (2004). The aim was to explain to the customers the major role of these nutrients in the body as well as their main sources. It was displayed on a desk at the entrance of the restaurant during the study.

A questionnaire with closed and semi-open questions was applied to the participants in this study to find out their age, gender, and education level and whether they had food allergies or intolerance, whether they had some disease that required dietary restriction; whether they had already consumed food after reading some unknown information about it or whether they had consumed food after reading information about its benefit to his/her health, as well the respondents' opinion about the food information. The respondents could answer "yes", or "no"; if they answered "yes", they were asked to identify the food in question. In the last question, the respondents could express their opinion by the following choices: "very good", "good", "regular", "bad", and "did not like".

The questionnaire was applied to 300 customers selected randomly during two weeks, who agreed to participate in the evaluation, and who were older than 18 years. The respondents were informed by the researcher about the study, and the questionnaire was handed out to be answered on the restaurant premises.

The questionnaire used with the restaurant customers was previously tested through an experimental study conducted in January in that same year.

Due to the involvement with humans, this research was sent to the Committee of Ethics and Research (CEP) of the Franciscan University Center (UNIFRA), according to the resolution 196/1996 of the National Health Council, which regulates the ethics of studies in humans (BRASIL, 1996).

The research was carried out only after the approval of the CEP under the registration $n^{\circ}$ 321.2008.2.

Since it is a quantitative research, the data were analyzed using statistical calculations (mean and percentage) using Microsoft Excel 2007.

\section{Results and discussion}

Of the 300 questionnaires, 54 were excluded because the respondents either did not answer any of the questions or they wrongly marked more than one answer for some questions, resulting in a total of 246 completed questionnaires.

Through the literature review conducted, it was possible to observe that the availability of food information in restaurants in Brazil is still poor and rarely discussed although access to this information is important to the health of the consumers.

The sample was composed of $58.54 \%$ females and $41.46 \%$ males, and $49.19 \%$ had a college degree and were aged between 18 and 28 years old (42.68\%), as shown in Table 1. A study that correlated gender with the use of nutritional information pertaining to calories in a fast-food restaurant network found that women who received information chose significantly lower calorie meals than women who did not receive any information.

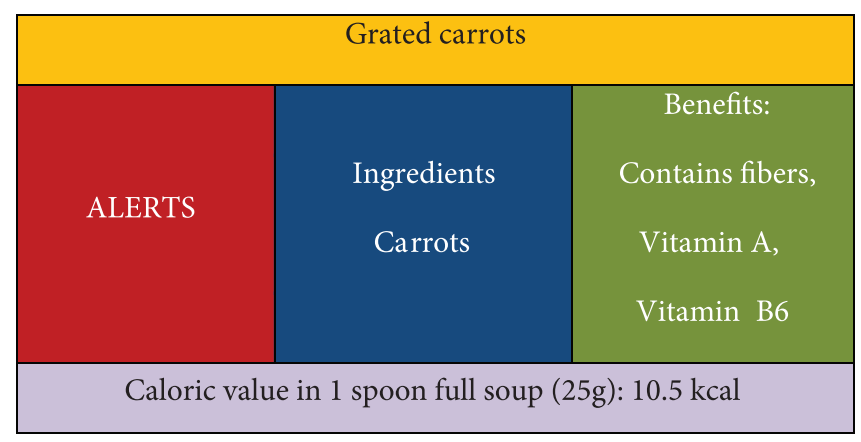

Figure 1. Food information model, adapted from Oliveira (2008), for preparations served in a commercial restaurant in Santa Maria (RS), 2009.

Table 1. Profile of survey participants on food information in a commercial restaurant in Santa Maria (RS), 2009.

\begin{tabular}{lcc}
\hline \multicolumn{1}{c}{ Variables } & $\mathrm{n}$ & $\%$ \\
\hline Gender & & \\
Female & 144 & 58.54 \\
Male & 102 & 41.46 \\
Age & & \\
$18 \mid--28$ & 105 & 42.68 \\
$28 \mid--38$ & 67 & 27.24 \\
$38 \mid--48$ & 30 & 12.20 \\
$48 \mid--58$ & 32 & 13.01 \\
$58 \mid--68$ & 8 & 3.25 \\
$68 \mid--78$ & 4 & 1.63 \\
Schooling & & \\
Incomplete elementary school & 2 & 0.81 \\
Completed elementary school & 1 & 0.41 \\
Incomplete high school & 3 & 1.22 \\
Complete high school & 35 & 14.23 \\
Incomplete higher & 80 & 32.52 \\
Complete upper & 121 & 49.19 \\
Other & 4 & 1.63 \\
\hline
\end{tabular}


It was also noted that providing calorie information had no effect on the food choices of men. Men tended to consume more calories per meal when calorie information was provided than when it was not provided; however, this difference was not statistically significant (GEREND, 2009).

Nevertheless, in a study that investigated the behavior of the employees and students at a university, it was found that the members of the staff were the most likely to observe the energy value information of prepared dishes; one of the justifications for this finding is that the employees were older (SILVA, 2006). Yamamoto et al. (2005), in their study on three fast-food restaurants, observed that offering information on the calorie and fat content of the food on the menus did not change the food choices of adolescents since $71.00 \%$ of the adolescents participating in this survey did not change their orders after being shown the calorie and fat content of the preparations.

In the present study, it was observed that $10.57 \%$ of the respondents reported allergies or food intolerances and that $10.98 \%$ reported diseases that require moderate consumption and/or total restriction on the consumption of some foods, as shown in Figure 2.

The data obtained in the present study corroborated with those of the family budget survey disclosed by the Brazilian Institute of Geography and Statistics (IBGE), in which $82.00 \%$ of Brazilians were found to consume excess saturated fat and more than $60.00 \%$ of the population exceeded the boundaries of sugar intake. The study also highlights the influence of calories consumed out of the house, representing $16.20 \%$ of the total average daily energy consumption of Brazilians (INSTITUTO..., 2012).

Therefore, it is necessary to offer information about food preparations to assure customers about food safety. This finding is supported by the study of Sanches (2007), who, when investigating nutritional information, found that approximately $78.00 \%$ of the consumers "strongly agreed" that nutritional information on foods offered in restaurants is extremely necessary to those who need a specific diet. However, the study by Maestro and Salay (2008), which aimed to identify the initiatives offering nutritional and health information in both fast-food and full service commercial restaurants in the city of Campinas (SP), found that only 29 of 114 companies provide health and nutritional information related to their food service, accounting for $25.40 \%$ of the surveyed sample.

In contrast, the present study found that $84.96 \%$ of respondents answered "no" when asked if they had avoided consuming any food because it presented a risk to their health, showing that the provided nutritional information did not have influence on most consumer choices. These data confirm the findings of Silva (2006) regarding to calorie information offered on preparations by restaurants, which in general is less observed than the nutrition label on industrialized food packaging labels and has less influence on consumer choices in general. According to a study by Salay (2003), consumers are not very concerned about some nutritional information of foods, so companies have little incentive to provide this information. This underlines the importance of educational activities with the community to enhance awareness of the relevance of the nutritional quality of foods for health promotion and disease prevention.

A positive aspect was that $58.54 \%$ of the respondents reported having consumed some food after finding out about their benefit to health, as shown in Figure 3, in accordance with the study by Krukowski et al. (2007), in which the majority of the respondents proved to be susceptible to the use of food labels in restaurants if available.

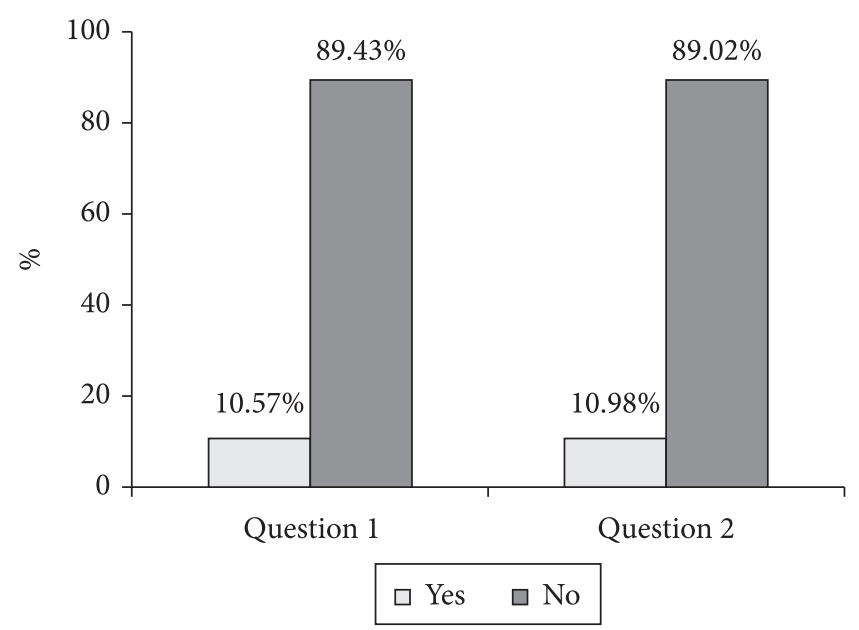

Figure 2. Percentage of intolerances and diseases in survey participants in a commercial restaurant in Santa Maria (RS), 2009. Caption: Question 1: Do you have an intolerance and/or allergy to any type of food?; Question 2: Do you have any type of disease that requires the constraint or moderation of a type of food?

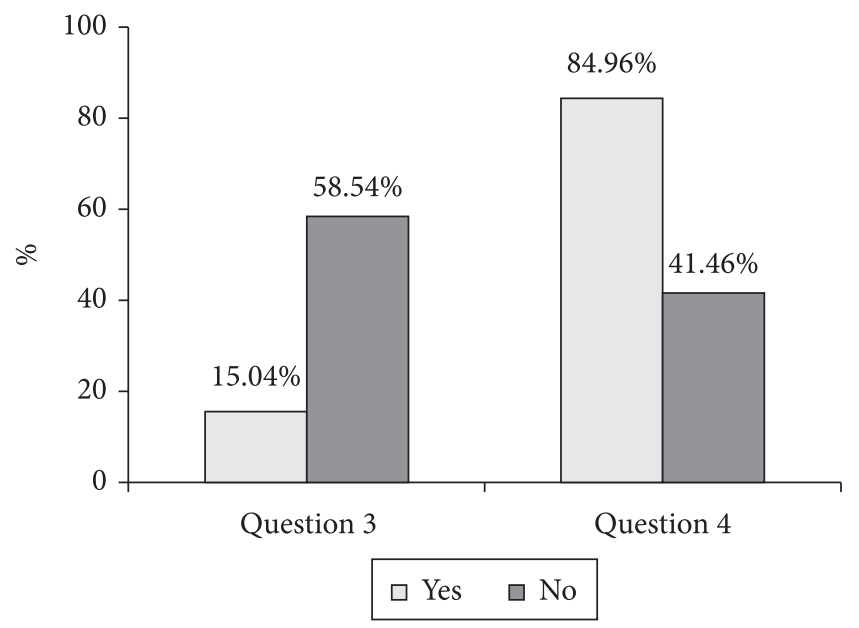

Figure 3. Percentage of participants who consumed and who did not consume food based on the nutritional information provided in a commercial restaurant in Santa Maria (RS), 2009. Caption: Question 3 : When you chose your food, did you exclude any food because you observed some nutritional information that you were previously unaware of about that food?; Question 4: When you chose your food, did you include any food because you observed that it had benefits to your health? 
Lando and Labine-Wolfe (2007) found that the respondents were interested in knowing the nutritional information available, but they would not use it on every occasion they were eating; they thought that those foods should be labeled by a single service or organ and suggested that the use of icons, labels, and signs on the menu indicating healthier options could be useful.

When the respondents were questioned about their satisfaction with the food information, $72.76 \%$ answered "very good", as can be seen in Figure 4. Sanches (2007) found that $54.80 \%$ of the respondents revealed a very positive attitude in relation to the nutritional information available in restaurants.

Yamamoto et al. (2005) concluded that the provision of nutrition information should be encouraged because it resulted in the reduction of some calorie and fat intake, based on the choices of adolescents, and did not negatively impact the restaurants. Hwang and Lorenzen (2008) also found that nutritional information on menus at restaurants can help customers to make healthy food choices.

Consistent with the results observed in this study, Thomas and Mills (2006), in a study about nutritional information in restaurants, found that many consumers feel that it is the responsibility of restaurants to inform them about the nutritional content of foods that can be harmful to their health or contrary to their beliefs.

Although there is little information about the nutritional content of preparations in restaurants, it is possible to envision a more widespread use. Therefore, the necessity for nutritional education of consumers becomes apparent, so that they can make good use of this information to promote a healthy diet.

However, it was observed in the present study that food information has been only partially accepted by consumers because approximately $85.00 \%$ of the respondents who had dietary restrictions did not change their choices during the meal, even if the preparation presented components that were harmful to their health.

It becomes essential for nutritional information to be provided by food services to improve the level of knowledge among consumers making them more selective about their meal

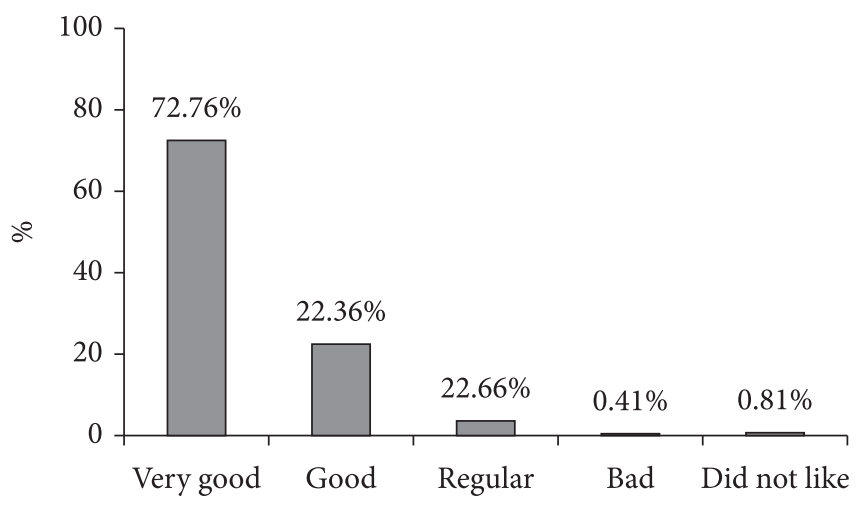

Figure 4. Percentage of satisfaction of the participants about the food information provided in a commercial restaurant in Santa Maria (RS), 2009. choices. Thus, restaurants are encouraged to offer healthier foods to meet customers' expectations.

\section{Conclusions}

It can be concluded that the most respondents did not change their eating habits about foods that pose risks to their health. However, they chose some specific foods noticed after finding out about their benefit to their health. These results demonstrate that customers have a tendency to change their eating habits after having access to food information on dishes, but a greater effect could be achieved with the education of the community.

Therefore, further studies are necessary, so that consumers can be encouraged to use nutritional information to build good eating habits and become more critical regarding the nutritional quality of food offered by restaurants.

\section{References}

ARAÚJO, M. O. D.; GUERRA, T. M. M. Alimentos per-capita. 2. ed. Natal: UFRN Ed. Universitária, 1995. 272 p.

BRASIL. Conselho Nacional de Saúde. Resolução no 196 de 10 de outubro de 1996. Regulamenta a ética em pesquisa em seres humanos no país. Diário Oficial da República Federativa do Brasil, Brasília, DF, out. 1996. Disponível em: <http://conselho. saude.gov.br/resolucoes/reso_96.htm> Acesso em: 20 mai. 2009.

BRASIL. Agência Nacional De Vigilância Sanitária - ANVISA. Resolução RDC no 360, de 23 de dezembro de 2003. Regulamento técnico sobre rotulagem nutricional de alimentos embalados, tornando obrigatória a rotulagem nutricional. Diário Oficial da República Federativa do Brasil, Brasília, DF, dez. 2003a. Disponível em: <http://www.anvisa.gov.br>. Acesso em: 25 maio 2009.

BRASIL. Agência Nacional de Vigilância Sanitária. Resolução RDC $n^{\circ} 359$, de 23 dezembro de 2003. Regulamento técnico de porções de alimentos embalados para fins de rotulagem nutricional. Diário Oficial da República Federativa do Brasil, Brasília, DF, dez. 2003b. Disponível em: <http://www.anvisa.gov.br>. Acesso em: 20 maio 2009.

CELESTE, R. K. Comparative analysis of the Brazilian/Mercosul and British/European Union food labeling legislation. Revista de Saúde Pública, v. 35, n. 3, p. 217-223, 2001. http://dx.doi.org/10.1590/ S0034-89102001000300001

COUTINHO, J. G.; RECINE, E. International experiences with health claims in food labeling. Revista Panamericana de Salud Publica, v. 22 , n. 6 , p. $432-437,2007$. http://dx.doi.org/10.1590/S102049892007001100012

CRAVEIRO, A. C.; CRAVEIRO, A. A. Alimentos funcionais: a nova revolução. Fortaleza: PADETEC, 2003. 281 p.

GEREND, M. A. Does Calorie Information Promote Lower Calorie Fast Food Choices Among College Students? Journal of Adolescent Health, v. 1, n. 44, p. 84-86, 2009. PMid:19101463. http://dx.doi. org/10.1016/j.jadohealth.2008.06.014

HWANG, J.; LORENZEN, C. L. Effective nutrition labeling of restaurant menu and pricing of healthy menu. Journal of Foodservice, v. 19 , n. 5 , p. $270-276,2008$. http://dx.doi.org/10.1111/j.17480159.2008.00108.x

INSTITUTO BRASILEIRO DE GEOGRAFIA E ESTATÍSTICA - IBGE. Estudo Nacional da Despesa Familiar: Tabela de composição de alimentos/IBGE. 4. ed. Rio de Janeiro: IBGE, 1996. 
INSTITUTO BRASILEIRO DE GEOGRAFIA E ESTATÍSTICA - IBGE. Pesquisa de Orçamentos Familiares. IBGE, 2012. Disponível em: <http://www.ibge.gov.br/home/presidencia/noticiasphp?id_ noticia=2084>. Acesso em: 01 jun. 2012.

KRUKOWSKI, R. A. et al. Consumers may not use or understand calorie labeling in restaurants. Journal American Dietetic Association, v. 1, n. 107, p. 33-34, 2007.

LANDO, A. M.; LABINER-WOLFE, J. Helping consumers make more healthful food choices: consumer views on modifying food labels and providing point-of-purchase nutrition information at quickservice restaurants. Journal of Nutrition Education Behavior, v. 3, n. 39, p. 157-163, 2007. PMid:17493566. http://dx.doi.org/10.1016/j. jneb.2006.12.010

LEÃO, L. S. C. S.; GOMES, M. C. R. Manual de Nutrição clínica: para atendimento ambulatorial do adulto. Petrópolis: Vozes, 2006. 168 p.

LOBANCO, C. M. Rotulagem nutricional de alimentos salgados e doces consumidos por crianças e adolescentes. 2007. $107 \mathrm{f}$. Dissertação (Mestrado em Saúde Pública)-Faculdade de Saúde Pública, Universidade de São Paulo, São Paulo, 2007.

LUNA, N. M. M. Técnica dietética: Pesos e medidas em alimentos. Cuiabá: Ed. UFMT, 1995. 21 p.

LUNA, N. M. M.; TEIXEIRA, A. B. Técnica Dietética: Fator de correção em alimentos de origem animal e vegetal. Cuiabá: Studio Press Editora e Comunicação Ltda, 1996. 12 p.

MAESTRO, V. Análise do oferecimento da informação nutricional e de saúde em restaurantes comerciais do município de CampinasSP. 2007. 182 f. Tese (Doutorado em Alimentos e Nutrição)Faculdade de Engenharia de Alimentos, Universidade Estadual de Campinas, Campinas, 2007.

MAESTRO, V.; SALAY, E. Informações nutricionais e de saúde disponibilizadas aos consumidores por restaurantes comerciais, tipo fast food e full service. Ciência e Tecnologia de Alimentos, v. 28 , p. 208-216, dez. 2008. http://dx.doi.org/10.1590/S010120612008000500032

MAHAN, K. L.; ESCOTT-STUMP, S. Alimentos, nutrição e dietoterapia. 11. ed. São Paulo: Roca, 2005. 1358 p.

MURA, J. D. P.; SILVA, S. M. C. S. Tratado de alimentação, nutrição e dietoterapia. São Paulo: Roca, 2007. 1168 p.
OLIVEIRA, R. C. DIAN - bufê: Disponibilização de informações alimentares e nutricionais em bufês. 2008. 128 f. Dissertação (Mestrado em Nutrição)-Universidade Federal de Santa Catarina, Florianópolis, 2008.

SALAY, E. Informação nutricional e mercado: um desafio para o governo e a universidade. UNICAMP, 2003. Disponível em: <http:// www.unicamp.br/imprensa>. Acesso em: 28 nov. 2003.

SALAY, E. Serviços de alimentação: crescimento acelerado. Agroanalysis, v. 21, n. 2, p. 47- 49. 2001.

SANCHES, M. Alimentação fora do domicílio: a atitude do consumidor frente à informação nutricional dos alimentos disponibilizada por restaurantes, Campinas-SP. 2007. 186 f. Tese (Doutorado em Alimentos e Nutrição)-Faculdade de Engenharia de Alimentos, Universidade Estadual de Campinas, Campinas, 2007.

SANTOS, J. S. et al. Anthropometric profile and food intake of adolescents in Teixeira de Freitas - Bahia. Revista de Nutrição, v. 18, n. 5, p. 623- 632, 2005.

SILVA, M. E. M. Repercussão da informação nutricional sobre o comportamento de clientes de restaurantes universitários. 2006. 182 f. Dissertação (Mestrado em Saúde Pública)-Faculdade de Saúde Pública, Universidade de São Paulo, São Paulo, 2006. http://dx.doi.org/10.1111/j.17454506.2006.00015.x

THOMAS, J. R. L.; MILLS, J. E. Consumer knowledge and expectations of restaurant menus and their governing legislation: a qualitative assessment. Journal of Foodservice, v. 17, n. 1, p. 6-22, 2006.

UNIVERSIDADE ESTADUAL DE CAMPINAS - UNICAMP. Tabela brasileira de composição de alimentos - TACO. versão 1. São Paulo: UNICAMP/NEPA, 2004. 114 p.

WAITZBERG, D. L. Nutrição oral, enteral e parenteral na prática clínica. 3. ed. São Paulo: Editora Atheneu, 2004. 1858 p. PMid:16227125. http://dx.doi.org/10.1016/j.jadohealth.2004.10.002

YAMAMOTO, J. A. et al. Adolescent fast food and restaurant ordering behavior with and without calorie and fat content menu information. Journal of Adolescent Health, v. 37, n. 1, p. 397-402, 2005. http:// dx.doi.org/10.1590/S1415-52732007000100002

ZANDONADI, R. P. et al. Atitudes de risco do consumidor em restaurantes de auto-serviço. Revista de Nutrição, v. 20, n. 1, p. 19-26, 2007. 